\title{
Another Silicon Valley? Tracking the role of entrepreneurship culture in start-up and venture capital co-evolution in Finland's entrepreneurial ecosystem 1980-1997
}

Sakari Sipola

Department on Marketing, Management and International Business, University of Oulu Business School, Oulu, Finland

\begin{abstract}
Purpose - The purpose of this paper is to examine how entrepreneurship culture affects start-up and venture capital co-evolution during the early evolution of an entrepreneurial ecosystem (EE) and its ability to foster the emergence of ambitious entrepreneurship as an outcome of its activity. Unlike studies that capture entrepreneurship culture at the national level, this study focusses specifically on the culture of venture capital-financed entrepreneurship and understanding its implications to the development of venture capital markets and successful firm-level outcomes within ecosystems.
\end{abstract}

Design/methodology/approach - Relying on EE and organisational imprinting theory, this study specifies characteristics of venture capital-financed entrepreneurship of Silicon Valley to illustrate the American way of building start-ups and examine whether they have as imprints affected to the entrepreneurship culture and start-up and venture capital co-evolution in Finland during the early evolution of its EE between 1980 and 1997.

Findings - The results illustrate venture capital-financed entrepreneurship culture as a specific example of entrepreneurship culture beneath the national level that can vary across geographies like the findings concerning Finland demonstrate. The findings show that this specific culture matters through having an impact on the structural evolution and performance of EEs and on the ways how they deliver or fail to deliver benefits to entrepreneurs.

Originality/value - The results show that venture capital-financed entrepreneurship and the emergence of success stories as outcomes of start-up and venture capital co-evolution within an EE are connected to a specific type of entrepreneurship culture. This paper also contributes to the literature by connecting the fundamentals of organisational imprinting to $\mathrm{EE}$ research.

Keywords Venture capital, Entrepreneurial ecosystem, Emerging markets, Silicon Valley, Ambitious entrepreneurship, Organisational imprinting

Paper type Research paper

(C) Sakari Sipola. Published by Emerald Publishing Limited. This article is published under the Creative Commons Attribution (CC BY 4.0) licence. Anyone may reproduce, distribute, translate and create derivative works of this article (for both commercial and non-commercial purposes), subject to full attribution to the original publication and authors. The full terms of this licence maybe seen at http://creativecommons.org/licences/by/4.0/legalcode

The author wishes to thank Valtteri Skantsi for assistance in data collection.
Received 26 August 2020 Revised 8 January 2021 24 February 2021 Accepted 26 March 2021 


\section{JEEE 14,3}

\section{Introduction}

Entrepreneurial ecosystem (EE) has become an essential and promising research topic at the intersection of entrepreneurship and economic development (Tsujimoto et al., 2017; Cavallo et al., 2019; Roundy and Bayer, 2019; Harima et al., 2020). EE research uses a systemic view of entrepreneurship (Acs et al., 2014; Song, 2019) with a focus on understanding the functioning of interdependent actors-particularly entrepreneurs-and factors that enable productive entrepreneurship to emerge as the output of their activity (Stam, 2015). The output consists of different types of entrepreneurship (Morris et al., 2015; Stam and van de Ven, 2019) with an emphasis on ambitious entrepreneurship (Alvedalen and Boschma, 2017) via fostering the creation of high-growth firms (Spigel and Harrison, 2018) and, at best, unicorns (start-ups with over $\$ 1$ bn private or public market valuation) which both are suggested as key performance indicators for EE (Acs et al., 2017). The latter types of entrepreneurship are especially sought after by policymakers as a small number of rapidly growing outlier firms make a substantial contribution to job creation out of total entrepreneurial activity (Crawford et al., 2015). At the policy level, the status quo is no longer only about fostering the quantity of new firm establishment (Shane, 2009); policies of the European Union, for instance, "aim to give Europe's many innovative entrepreneurs every opportunity to become world-leading companies" [1].

The increased ambition level towards entrepreneurial outcomes emphasises the importance of context in innovative entrepreneurship (Autio et al., 2014). Entrepreneurs located in established EEs such as Silicon Valley (Saxenian, 1994) or Israel (Senor and Singer, 2009), are from the outset exposed to decades of accumulated knowledge, networks and resources specific to support innovative start-ups and their growth. Within the context of nascent and small-town EEs (Florida and Hathaway, 2018; Roundy, 2017b) such systemic conditions are not correspondingly available for entrepreneurs as the interdependent structural EE elements are not yet established but co-evolve during the early evolution phase, depending on the preconditions of the geography (Malecki, 2018; Stam and van de Ven, 2019). The differences in context, therefore, affect the ways of the EE to support or constrain different types of entrepreneurship and related outcomes (cf. Lippmann and Aldrich, 2016).

Although the importance of context is recognised in the EE literature, previous studies have emphasised the documentation of economic and structural factors of single ecosystems such as the formal actor structure of an EE (Stam, 2015; Mack and Mayer, 2016). These studies typically focus on successful examples (Spigel and Harrison, 2018) and use a static framework without considering the emergence process and evolution of EE elements in time (Alvedalen and Boschma, 2017; Motoyama and Knowlton, 2017; Malecki, 2018). Literature is currently underdeveloped regarding the relevance of connections between the identified EE elements, their spatial scale and co-evolution and their impact on the performance of EEs (Alvedalen and Boschma, 2017; Stam and van de Ven, 2019). Moreover, the role of historically developed contextual conditions, institutional logics and understanding of their functioning at present are under-explored (Auerswald, 2015; Roundy, 2017a; Harima et al., 2020). Recent review of the EE field (Cavallo et al., 2019) suggests that scholars could take a narrower focus by studying a smaller set of ecosystem elements instead of attempting to model the whole EE and its relationships.

In this article, we study the role of entrepreneurship culture (an informal institution) in the early evolution of EEs. We limit our focus on a subset of EE structure (Cavallo et al., 2019) and examine entrepreneurship culture in connection to high-growth entrepreneurship and venture capital as EE elements that are mutually interdependent and co-evolve in a territory (Stam and van de Ven, 2019). The culture of entrepreneurship and access to 
financial resources and the ways they affect the entrepreneur and the types of ventures they start are important for the functioning of an EE (Acs et al., 2017). We examine the chosen elements longitudinally to understand their emergence, co-evolution and implications to entrepreneurship during the early phases of EE evolution (Alvedalen and Boschma, 2017; Motoyama and Knowlton, 2017; Malecki, 2018). We find support for this approach from research on the early evolution of the entrepreneurial context of Israel. Avnimelech and Teubal (2006) illustrate the start-up and venture capital co-evolution and the importance of their mutual interdependence for outcomes in ambitious entrepreneurship, during the early evolution of the entrepreneurial context of Israel. Based on Breznitz $(2006,2007)$, we postulate that related to the start-up-venture capital -relationship, a culture of closely imitating the American mode of start-up growth was at a place as an informal institution and became the modus operandi directing the activity of entrepreneurs and venture capitalists. We see that the role of this type of specific entrepreneurship culture and its influence on outcomes of $\mathrm{EE}$ activity is not properly addressed in current theory (cf. Fritsch and Wyrwich, 2014).

Empirically, we aim to better understand the development and role of entrepreneurship culture in the start-up and venture capital co-evolution of Finland during the early evolution of $\mathrm{EE}$ and in relation to the lack of high-growth firms and success stories as an outcome of its $\mathrm{EE}$ activity, until a recent decade. Inspired by the case of Israel, we use Silicon Valley as an example of successful $\mathrm{EE}$ and venture capital-financed entrepreneurship culture to study how the American mode of start-up growth was depicted in Finland at the cultural level. This is important as benchmarking is a relevant economic development practice (Blakely and Leigh, 2010) that regions and policymakers are using in developing local EEs. Indeed, the only recent globalisation of venture capital outside of the US (Florida and Hathaway, 2018) has brought this specific type of entrepreneurship and related culture to EEs of new geographies of which many are addressing start-up and venture capital co-evolution at their early evolution phase (Karsai, 2018). How the entrepreneurship culture is created and what its implications are at EEs of different geographies are still open questions (Alvedalen and Boschma, 2017). Our research question is: How does the entrepreneurship culture affect start-up and venture capital co-evolution during the early evolution of EEs?

The paper is structured as follows. After the introductory section, the literature on EE and organisational imprinting is discussed as the theoretical basis of the study. This is followed by the research methodology, data and reasoning of Finland as a chosen research site. Thereafter, the history of Silicon Valley and its characteristic entrepreneurship activity are summarised from an imprinting perspective. This is followed by an analysis of how the Silicon Valley and American start-up mode imprints impacted the early co-evolution of start-ups and venture capital in the EE of Finland between 1980 and 1997. Conclusions close the paper by discussing the contribution it makes, the Finland-related findings and their applicability to EEs in other geographies.

\section{Entrepreneurial ecosystem as a context for organisational imprinting \\ Entrepreneurial ecosystem}

The roots of the EE concept can be traced to the works of Tansley (1935) in biology and Moore (1993), who discussed business ecosystems in the management literature (Cavallo et al., 2019; Stam and van de Ven, 2019) and Bahrami and Evans (1995) study in which the term ecosystem was used to examine entrepreneurship of Silicon Valley. In recent years EE research has gradually become one of the most popular research subjects at the intersection of entrepreneurship and economic development (Tsujimoto et al., 2017; Roundy and Bayer, 2019; Harima et al., 2020). It has been examined, for instance, in relation to technology and 
JEEE
14,3

innovation management (Adner and Kapoor, 2010; Kapoor and Lee, 2013; Pierce, 2009), innovation (Gomes et al., 2016; Jacobides et al., 2018; Malecki, 2018) and regional and national innovation systems (Acs et al., 2017; Stam, 2015) with significant inspiration coming from practitioners such as Feld (2012).

Within entrepreneurship literature, the EE concept is reasoned by outlining its position in contrast with research on clusters, industrial districts and various innovation systems (Stam and Spigel, 2017; see also Harima et al., 2020). Although these approaches share the focus on the external business environment and intra-industry assets, EE underlines the importance of entrepreneurs, rather than public officials, as drivers of ecosystem development and its vitality in the long term without industry limitations (Stam, 2015; Spigel, 2016; Cavallo et al., 2019). The entrepreneurs are seen not to operate in isolation (Autio et al., 2014) but within a region whose EE attributes contribute to the competitiveness of a new venture and the entrepreneurship process (Spigel, 2017). A distinctive feature and justification of the EE as opposed to the other approaches are its particular focus on highgrowth entrepreneurship and, as recently proposed by Acs et al. (2017), unicorns and the examination of the ability of some regions to continuously produce high-growth entrepreneurial ventures as the output of EE activity (Mason and Brown, 2014; Acs et al., 2017; Spigel and Harrison, 2018).

The increase in ecosystem research has resulted in many EE definitions and frameworks of which a shared agreement is missing amongst scholars and practitioners (Credit et al., 2018; Cavallo et al., 2019; Stam and van de Ven, 2019). Early studies focussed to identify and list structural EE components and attributes of mostly successful examples (Stam, 2015; Mack and Mayer, 2016; Spigel and Harrison, 2018) whereas the evolution of EEs and interaction of their different components are more recent research areas (Alvedalen and Boschma, 2017; Roundy and Bayer, 2019). The definition of Isenberg (2010) aptly describes how EE attempts to capture activity on six domains (policy, finance, culture, support, human capital and markets), each containing a high number of interacting elements that vary across geographical contexts; this makes a unified definition challenging but also identifies that general causal paths have limited value in this context (Auerswald, 2015). Out of the systemic entrepreneurship definitions in EE research, we find the work of Acs et al. (2014) and Stam and van de Ven (2019) as particularly suitable for this study.

Acs et al. (2014) define systems of entrepreneurship as "resource allocation systems that are driven by individual-level opportunity pursuit, through the creation of new ventures, with this activity and its outcomes regulated by country-specific institutional characteristics". Stam and van de Ven (2019) develop an integrative EE model that consists of 10 mutually interdependent and co-evolving elements. Productive entrepreneurship is caused by the interaction of the elements which helps to explain the level of regional entrepreneurial activity, particularly by the contribution of successful firms and individuals back to the EE and its future development (Bahrami and Evans, 1995; Mason and Harrison, 2006). The $10 \mathrm{EE}$ elements as operational constructs are divided into components of institutional arrangement (formal institutions, culture and networks) and resource endowment (physical infrastructure, demand, intermediaries, talent, knowledge, leadership and finance) that form the infrastructure for entrepreneurship (van de Ven, 1993).

The focus of this study on entrepreneurship culture (as an informal institution), highgrowth entrepreneurship/start-ups and venture capital finance as a subset of EE structure (Cavallo et al., 2019) and the reasons for approaching the EE literature through them, can be discussed in relation of the two above studies. Firstly, we see that defining the EE as a system of resource allocation supports our focus on the chosen EE elements. Venture capital-financed entrepreneurship-this is what our chosen elements embody-fundamentally 
consist of resource allocation from the EE to high-growth potential ventures to finance and support their growth at different phases of the firm life cycle. Inherent in this type of entrepreneurship is the commitment or agency of firm management to pursue high-growth opportunities as a means for achieving an exit (initial public offering (IPO) or trade sale) that is required at some point of venture capital-financed firms. The life cycle (around 10-years) of venture capital funds is designed to provide the invested firms time for reaching the exit point (cf. Gompers and Lerner, 2004).

The above discussed further connects with the role of $\mathrm{EE}$ as the regulator of outcomes of entrepreneurial action (Acs et al., 2014). The progress of venture capital-financed firms is monitored by investors and produces, not only successful exits of firms but also a regulated failure as an outcome when struggling firms are not able to achieve set targets, turn around the business and raise further finance from investors, and hence exit by failure. Venture capital as resource allocation to specific types of firms (Morris et al., 2015) and support of their growth is, therefore, suitable for capturing the functioning of an EE targeting high-growth firms as the sought output (Spigel and Harrison, 2018). Moreover, if the suggestion of placing unicorns as a key performance measure of EE (Acs et al., 2017) is applied, the importance of venture capitalfinanced entrepreneurship cannot be neglected: recent listing of 500 unicorn firms globally illustrates that in principle each one is venture capital-financed [2].

Secondly, out of the EE elements in the focus of this study, culture represents informal institutions within the institutional arrangement component and venture capital illustrates finance inside the resource endowment component of the EE model by Stam and van de Ven (2019). Venture capital-financed entrepreneurship manifests as the emergence of highgrowth firms (of which some can reach the unicorn status) as one form of productive entrepreneurship. With this limited focus, we also aim to increase knowledge of how the different EE elements are connected (Alvedalen and Boschma, 2017). The aspect of mutual interdependence and co-evolution highlighted by Stam and van de Ven is evident between start-ups and venture capital; the latter does not exist without the success of the former and the risk-taking required by the former is difficult (not impossible) to carry without the finance of latter. However, the agency of their coupled activity does not solely come from this formal structure-level connection but is, in our view, affected by the specific entrepreneurship culture around venture capital-financed entrepreneurship of the EE context where the actors are embedded.

Indeed, scholars have begun to show more interest in the role of informal institutions, cultural artefacts and narratives in the functioning and evolution of EEs (Mack and Mayer, 2016; Roundy, 2017a; Spigel, 2017; Roundy and Bayer, 2019; Harima et al., 2020). Institutions divided broadly between formal (legislations, regulations, economic systems) and informal (customs, norms, traditions) are seen to collectively define the system of written and unwritten rules (North, 1990) that shape the attitudes, values and expectations of individual economic actors (Gertler, 2004, 2010) and entrepreneurship regionally (Andersson and Henrekson, 2015). Due to this embeddedness, informal institutions impose constraints both on formal institutions (rules of the game) and governance (play of the game) structures (Williamson, 2000). Although the role of entrepreneurship culture is discussed in related entrepreneurship research (Spigel, 2017), the majority of studies attempt to explain it via the influence of national-level entrepreneurship culture on the rates of entrepreneurship at different geographies (Hayton and Cacciotti, 2013). The degree of valuing entrepreneurship in a society (Fritsch and Wyrwich, 2014) or commonness of establishing new firms within a territory (Stam and van de Ven, 2019; see also Credit et al., 2018) are also used in this connection as direct and indirect measures. The knowledge and functioning of entrepreneurship culture as an informal institution below this national level is limited 
JEEE
14,3

(Credit et al., 2018). Alvedalen and Boschma (2017) made it possible to conclude that currently, we do not know enough of which institutions matter and have an impact on the EE structure and performance.

Another element regarding the entrepreneurship culture in the EE context relates to time and context. Informal institutions as socially constructed templates for action evolve over long periods of time, gradually acquire the moral and ontological status of taken-for-granted facts and become socially and contextually embedded (Barley and Tolbert, 1997). Current EE frameworks are rather static of this perspective and do not address evolution properly (Alvedalen and Boschma, 2017). Fritsch and Wyrwich (2014) propose that entrepreneurship culture could be seen as a form of capital because it does not only take longer to develop but can also be long-lasting. Indeed, well-functioning EEs such as Silicon Valley (Saxenian, 1994) or Israel (Senor and Singer, 2009) organised decades ago around the development of venture capital-financed firms (Gompers and Lerner, 2004) and carry within significant amounts of contextually embedded history, cultural attitudes (Spigel, 2017) and know-how of ambitious entrepreneurial activity (Lippmann and Aldrich, 2016). The understanding of both the rules and the play of such a game (Williamson, 2000) have sedimented in the entrepreneurial culture (cf. Tolbert and Zucker, 1996). As a corollary, opportunity shaping and resource allocation within the EE (Acs et al., 2014) are collectively approached via an ambitious growth perspective to which nascent entrepreneurs are exposed when they engage in dialogue with different ecosystem members (Mainela et al., 2018).

However, EEs are rarely complete in terms of having a critical mass of all elements in place or accessible via networks, for instance, the number of successful EEs attracting significant venture capital is still limited. Florida and Hathaway (2018) categorised only 30 cities as emerging (growing) start-up hubs or EEs globally. The availability of early-stage finance, examples of successful entrepreneurs, relevant networks and support organisations for entrepreneurship can be lacking in EEs of small cities in emerging markets (Roundy, 2017b). As Karsai (2018) documents, the development of venture capital markets is one important phase in the early evolution of $\mathrm{EE}$ towards fostering high-growth entrepreneurship. Although pioneering entrepreneurs and private actors have an important role in evolution (Lippmann and Aldrich, 2016), domestic venture capital market creation is difficult and often driven by public venture capital policy (Lerner, 2009). The entry of venture capital actors within an EE represents institutional change (cf. Alvedalen and Boschma, 2017) as venture capital-financed entrepreneurship is a new institution and can represent change especially of informal institution perspective as it requires a specific entrepreneurship culture. This means that the culture-an integral part of the start-upventure capital mutual interconnectedness and co-evolution-is to be created consciously or unconsciously in parallel. Based on Williamson (2000) we theorise that the culture of venture capital-financed entrepreneurship affects to rules of the game in creating a role and need for venture capital finance (as resource endowment component) and governing the play of the entrepreneurs and start-ups (institutional arrangement component) within the particular EE. How this specific culture is created and what its implications are for the performance of EEs of different geographies are still open questions (Alvedalen and Boschma, 2017).

Finally, to understand the emergence and functioning of institutions in EEs, the history of the ecosystem must be taken into account. This is mostly done in prior research by dividing the evolution of EEs into certain phases with specific characteristics. Mack and Mayer (2016) use four phases of birth, growth, sustainment and decline. Malecki (2018, p. 11) similarly applies four phases of nascent, evolving, mature and self-sustainable and notes four-phase modes to be common overall. Out of the phases birth (nascent) and growth (evolving) cover the early evolution and are relevant for this study. 
According to Mack and Mayer (2016, pp. 4-6) at the birth phase, most key components of EE such as availability of finance are underdeveloped, the amount of success stories and entrepreneurship-related human capital is limited but the number of firms increases slowly as more new firms are started than shutting down and support infrastructure for entrepreneurs begins to take shape. The growth phase is characterised by the emergence of first serial entrepreneurs and role models, the establishment of entrepreneurship education and regional policies to favour new firm creation which results in an increase of financial capital, network density and regional entrepreneurship culture and encourage entrepreneurs to aim for large markets outside the local region. At the birth and growth phase of development, the entrepreneurship culture, informal institutions and rules of the game are also created and written via the activity and perceptions of pioneering actors involved in the EE. Regions without a strong entrepreneurial resource pool can acquire them via resource injections to the EE (Roundy et al., 2018; Spigel and Harrison, 2018), for example, by attracting experienced transnational entrepreneurs to relocate and enrich the local environment (Harima et al., 2020). In light of the above, a significant share of the EEs can be placed to birth and growth phases, in particular those involved in venture-capital financed entrepreneurial activity.

\section{The concept of imprinting}

Originating from the work of Stinchcombe (1965), the concept of imprinting, the idea that elements of environmental conditions are imprinted in organisations at their founding, has received significant scholarly attention across many fields, amongst which entrepreneurship is a more recent entrant. Although imprinting as a concept is widely used in different types of analysis, it has been at the same time loosely defined and applied widely as an umbrella term, making the literature fragmented (Johnson, 2007; Marquis and Tilcsik, 2013). A common thread across this literature is the view that origin conditions matter for organisations and are crucial for understanding their development (Hannan et al., 1996). Differences in types of organisations are seen to result from various resources that are available in the context in which the organisations are founded.

Marquis and Tilcsik (2013, p. 196) document the origins of imprinting research in biology and discuss how in early studies, observations of animal behaviour right after their birth were used as original examples for the concept of imprinting. The work of Stinchcombe (1965) then connected imprinting in organisational research and stated that social and economic structures impact strongly on nascent organisations. In the following, we discuss three fundamental elements of imprinting to define the concept in detail.

The first fundamental element of imprinting is the notion of a sensitive period: a limited period of time when an organisation has high susceptibility for imprinting of the environmental factors to occur (Immelmann, 1975, p. 24). An opportunity window exists during which certain elements of the environment are stamped onto the new organisation (Johnson, 2007). Current literature suggests that, besides the founding stage, organisations have other periods of sensitivity for imprinting to occur during their development such as the moment when a firm goes public or is merged with or acquired by another firm (Marquis and Tilcsik, 2013). Sensitive periods, thus, occur at the key development stages of an organisation, not only at the time of founding (Carrol and Hannan, 2004).

The second fundamental element of imprinting is the imprint of the environmental factors to subjects during the sensitive period. Marquis and Tilcsik (2013) frame this as the stamp of the environment, meaning how core features of the environment influence the subject of imprinting such as individuals, teams, organisations or industries. The forces and characteristics residing in the environment as sources of imprinting include cultural, 
JEEE
14,3

economic, political and technical resources that as imprints make a certain type of organisational structures and practices both possible and desirable, and hence significantly influence the character and functioning of new organisations (Johnson, 2007; Simsek et al., 2015).

The third fundamental element of imprinting relates to the persistence of imprints. This addresses the question of how long the imprints remain in the imprinted subjects when conditions in the environment change and what type of metamorphosis - chance, transformation and evolution - takes place in the imprints (Marquis and Tilcsik, 2013; Simsek et al., 2015). In early studies, the persistence of imprints was examined in connection with organisational inertia, the tendency of an organisation to continue on its current trajectory as it matures and the role of initial structures in limiting the capacity of organisations to reshape themselves when their survival and growth is at risk (Hannan et al., 1996). An organisation's initial structural features are sustained by inertia, which increases the risk of mortality (Carrol and Hannan, 2004). Besides inertia, the persistence of organisational structures is seen as affected by institutions and institutionalisation. Marquis and Tilcsik (2013) see that prior imprints create generations of imprints that layer upon one another and institutionalise with the possibility of the old layered imprints to survive to some degree despite subsequent sensitive periods. They see the interface between dynamics of persistence and institutionalisation as one key future research area.

In sum, based on the above elements, Marquis and Tilcsik (2013) define imprinting as "a process where a focal entity develops characteristics that reflect prominent features of the environment and these characteristics continue to persist despite significant environmental changes in subsequent periods". In the following subsection, we proceed to define how the principles of imprinting connect with EE literature.

\section{Imprinting and entrepreneurial ecosystems}

In this section, EE and organisational imprinting discussions are connected at a theoretical level. We take the three fundamental elements of imprinting-sensitive period, imprinting of the environment factors and persistence of imprints-as the basis and position EE elements in relation to them. Firstly, as documented above, the requirement for imprinting to occur is the existence of sensitive period(s) when the subject has an opportunity window open for imprinting of the environmental factors to occur (Immelmann, 1975, p. 24; Johnson, 2007). We approach the development phases of EEs (Mack and Mayer, 2016; Malecki, 2018) and the notion of sensitive periods as equals, particularly in the case of birth and growth phases. We argue that EEs have their own sensitive periods for imprinting to occur, not only at the early evolution but during their processual development (Carrol and Hannan, 2004). The entry of the new type of institutional actor such as venture capital firms/finance to EE represents an example of a sensitive period within the early evolution context. Indeed, especially potential entrepreneurs and new ventures within an ecosystem have their own sensitive periods for imprinting to occur not only at the beginning but also during the later phases of the entrepreneurial process like at the exit phase.

The second element of imprinting is the actual imprinting of environmental factors on targets during the sensitive period(s). This captures how core features such as the cultural, economic, political and technical resources (Johnson, 2007) of the environment influence the targets of imprinting (Marquis and Tilcsik, 2013). As discussed above, we approach this from $\mathrm{EE}$ and in particular of venture capital-financed entrepreneurship and related entrepreneurship culture perspective. The establishment of venture capital funds includes the imprinting of environmental factors to the fund managers and their operational logic. Entrepreneurs and new ventures looking for finance are then exposed to these imprints 
coming from the venture capital firms which affects the development of the financed firms and makes venture capital-financed entrepreneurship possible and desirable.

The third fundamental of imprinting relates to the persistence of imprints in the targets of imprinting under changes in the environment. Previous studies discuss how maturing organisations develop inertia and stable structures and have a tendency to continue on the same track, which hampers their renewal and response to changes in the environmental and institutional context (Hannan et al., 1996). The earlier imprint generations are layered beneath the new imprints and can survive to some degree during new sensitive periods of imprinting (Marquis and Tilcsik, 2013). This relates to our focus on entrepreneurship culture as an embedded informal institution or capital form with a long development and lifetime (Barley and Tolbert, 1997; Fritsch and Wyrwich, 2014). We contrast these to imprinter characteristics such as institutional and cultural norms, history of success, shared experience and cognitions, experience and capabilities that are prevalent in imprinting theory (Simsek et al., 2015, p. 5). In sum, the fundamentals of organisational imprinting enable us to study how informal institution-level resources such as the culture of venture capital-financed entrepreneurship are stamped in the institutional realm of an EE and affect start-up and venture capital co-evolution and outcomes of related entrepreneurial activity.

\section{Methodology}

The focus of this article is on the role of entrepreneurship culture in start-up and venture capital co-evolution as means to foster high-growth firms during the early evolution of EE. As it was discussed, the previous literature of EEs is limited regarding the connections between different EE elements and how institutional arrangement components like embedded informal institutions affect resource endowment components and outcomes of EE activity. We aim to provide new knowledge on the role of venture capital-financed entrepreneurship and its specific form of an entrepreneurial culture with the EE context. We chose qualitative methods and case study as research strategy as they enable to address how questions that are typical in qualitative research and are suited with phenomena in which the role of contextual conditions is of interest (Yin, 1994; Welch et al., 2011). The importance given in this study to historical documentation further support this decision as case study methods have similarity with a historical review (Ghauri, 2004).

To advance knowledge of the chosen EE elements of this study, Finland was chosen as a research subject. As a country, it ranks amongst the most innovative (Dutta et al., 2017) and competitive (Schwab and Sala-i-Martín, 2016) countries globally with a long history of public investment and policy in supporting entrepreneurship. However, despite the diverse policy-based support mechanisms and robust technology and innovation preconditions, high-growth firms and exits of venture capital-financed firms as the output of the EE activity remained paradoxically absent for long (Deschryvere, 2008; Autio, 2009) and the performance of the Finnish EE was not aligned with its presumable good pre-conditions of entrepreneurship. Only during the past decade, the EE of Finland has taken significant improvement steps in start-ups and venture capital-financed entrepreneurship triggered by the downfall of Nokia's mobile phone business and increased start-up activities with unicorn firms such as Supercell as a flagship outcome.

On the contrary, the early evolution of the entrepreneurial context of Israel towards the so-called Start-up nation and one of the best performing EEs globally is well-documented (Avnimelech and Teubal, 2006; Senor and Singer, 2009: Wonglimpiyarat, 2016) and a rare example of successful emergence of venture capital-financed entrepreneurship to the national entrepreneurship sphere by late-1990s. As relevant for this study, Avnimelech and Teubal (2006) discuss the historical development of the entrepreneurial context and venture 
capital policies behind the successful start-up and venture capital co-evolution in Israel and show how their mutual interdependence was crucial in the early evolution phase. For example, venture capital policy (Yozma programme in 1993) connected experienced foreign venture capitalists with aspiring venture capitalists of Israel (resource injection) to learn about venture capital by investing together in Israeli start-ups (Senor and Singer, 2009, pp. 165-166). Based on Breznitz $(2006,2007)$ we postulate that behind this connection between start-ups and venture capital culture of imitating the American mode of start-up growth-the way how venture capital-financed firms organised to pursue IPO in the US-was also at a place in Israel during the early evolution. This became a key part of the emerging entrepreneurship culture that, as a modus operandi, began to direct the activity of entrepreneurs and venture capitalists and their co-evolution. The agency for the start-up and venture capital resource endowment came from imprints at the entrepreneurship culture level (cf. Stam and van de Ven, 2019).

Although the early evolution and performance differences between EEs of Finland and Israel motivate this study, we do not aim to explain them directly nor we aim to develop any testable propositions (Cuervo-Cazurra et al., 2016). The key components of early evolution in Israel took place around the same time as in Finland in the 1980s and 1990s and directs our interest in entrepreneurship culture and understanding its role as an informal institution in connection to venture capital policies and other activities relating to fostering of highgrowth entrepreneurship at the early evolution phase of the EE in Finland. The birth and growth phase characteristics (Mack and Mayer, 2016) make the early evolution phase of Finnish EE relevant to study as many regions are currently establishing their venture capital policies and funds to foster high-growth entrepreneurship via venture capitalfinanced firms. Particularly, we are interested to study if similar imprinting of the American mode of start-up growth to the entrepreneurship culture took place in Finland. We attempt to trace this by analysing how Silicon Valley, as a measure for the American mode of startup growth and entrepreneurship culture, was present and discussed in Finland during the early evolution of its EE.

\section{Data collection}

The empirical data of this study consists of two kinds of secondary data: archival and newspaper data. The archival data was collected from publicly available sources in Finland and includes policy briefs, committee reports and evaluations of public organisations and instruments such as the Finnish Industry Investment (FII, responsible for venture capital policy execution), the Fund for Developing Regions (KERA) and the Finnish Innovation Fund Sitra. These were typically written by academics, relevant professionals or firm representatives and commissioned by the Ministry of Trade and Industry or board of directors of the public organisations to evaluate the impact of related public expenditure. In addition, the data consisted of documents, annual reports and statistics of private organisations such as the Finnish Venture Capital Association (FVCA). The object of analysis varied from individual key organisations to the evaluation of the national innovation system. This data was organised into a 40-page-long case chronology that contained the main entrepreneurship, venture capital and firm growth-related structural developments such as the establishment of key public actors and contextual events/ conditions in Finland starting from the 1960s until the mid-2010s. Decades were used as time periods to make the case narrative more accurate (Miles and Huberman, 1994). Due to the chosen EE elements and interest in the early evolution of this study, we focussed especially on documentation, research and facts relating to venture capital policies and development of venture capital-financed entrepreneurship during the 1980s and 1990s 
including the identification and use of international examples such as the America or Silicon Valley as imprints.

The second kind of data consists of newspaper data that was collected from the electronic archives of Helsingin Sanomat, the largest privately-owned daily newspaper in Finland established in 1889. The daily circulation of the newspaper was 400.000 in 1981 amongst the 4.8 million population of Finland at the time making it the largest morning paper of Nordic countries. The role of this data was particularly related to the identification of possible imprints relating to Silicon Valley and its characteristic entrepreneurship culture. Using an online archive tool, we were able to access the exhaustive news coverage of the Finnish economy, institutions, policy and industrial development in the capital region of Helsinki and geographies elsewhere in Finland as Helsingin Sanomat had many regional editorial offices during our observation period. The use of one national newspaper, like Helsingin Sanomat with the largest domestic circulation, is considered to be a valid source of data (Barranco and Wisler, 1999). The online archive tool enabled us to access articles covering the time period up to 1997 and our data collection covers the years 1980-1997. Indeed, the time period until the year 1997 presents an era before the significant increase of information diffusion via the internet making the role of leading newspaper(s) central in public discussion and media communication, and therefore a medium for the imprinting process.

The newspaper data collection was conducted as a keyword search in the online archive using "Silicon Valley" and its Finnish translations (Piilaakso and Silikonilaakso) as the main search words. This search returned a total of 284 hits from the news archive. As an individual news article can contain both the English and Finnish words or the same keyword more than once, the findings were narrowed down to the total amount of news articles that contained either one or more of the keywords. This and the removal of search algorithm errors reduced the total amount to 247 newspaper articles that are used in the final analysis (Figure 1).

\section{Data analysis}

The data analysis and data collection were interwoven in the research process as is common in qualitative and interpretive studies (Miles and Huberman, 1994; Gephart, 2004). As the first analytic procedure, we used the chronological case story and focussed particularly on analysing the facts and development of venture capital-financed entrepreneurship and the evolution phase of the EE in Finland. We identified early evolution characteristics that are parallel with birth and growth phase descriptions of EE evolution. Finnish policymakers

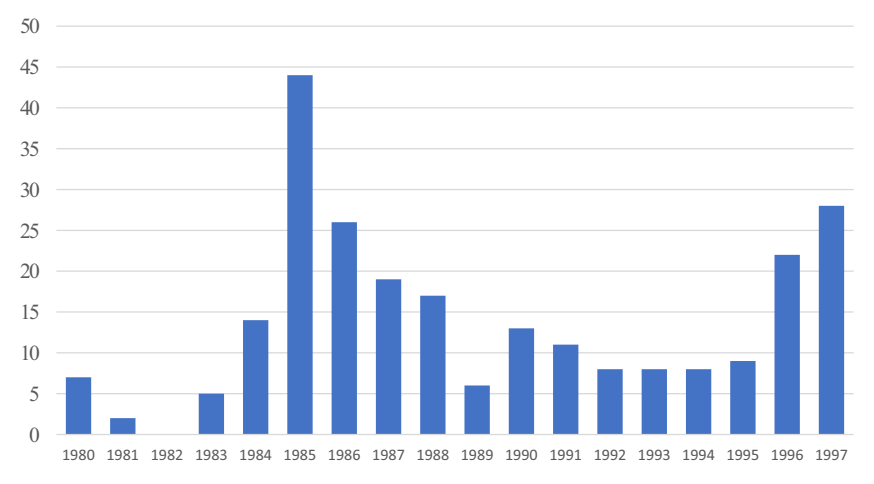

Figure 1. The total amount of newspaper articles containing the term "Silicon Valley", 1980-1997 
JEEE
14,3

480

had recognised the lack of venture capital-financed entrepreneurship in Finland and initiated programmes to developed domestic venture capital markets in the 1980s and 1990s. However, we found that the culture around venture capital-financed entrepreneurship was unclear and related practices underdeveloped. We noticed that many of the current active EE members in Finland such as Business Finland and Finnish Industry Investment were established already in the 1980s and 1990s. We calculated that between 1990 and 1997 venture capital investment in Finland was only $162 \mathrm{~m}$ euros in total. The archival data analysis also showed that the number of exits was not systemically documented in Finland and consisted of a limited number of exits mainly in domestic markets, we concluded that the amount of venture capital-financed entrepreneurship and high-growth firm success stories was limited (cf. Autio, 2009). These characteristics place the evolution of the Finnish EE to the birth and growth phase (Mack and Mayer, 2016) when the elements we focus on in this study are accounted for. We discuss these and related imprinting in more detail in the remaining sections of the paper.

As the second analytic procedure, we coded [3] and analysed the newspaper data to identify possible Silicon Valley-related imprints. We divided the coding into two major stages of first and second cycle coding (Saldaña, 2013). During the first cycle, we categorised the data by assigning codes to individual newspaper articles using entrepreneurship, venture capital and informal institutions as a start list of three codes that originate from our theory and aims of the study (Miles and Huberman, 1994; Ghauri, 2004). As is common in qualitative data collection and analysis, other codes inductively emerged during the analysis as the data began to organise (Miles and Huberman, 1994) and we ended up using three additional codes (geography and technology, concept and metaphor and irrelevant) resulting in six code categories in total that were used to summarise the data. As an individual news article can be given more than one code, the total number of codes given $(n=274)$ at the end of the first coding cycle was higher than the number of individual news articles $(n=247)$. The articles coded as irrelevant $(n=106)$ include for instance job, real estate and other media advertisements mentioning our key word(s).

The second cycle coding was focussed on identifying and constructing pattern codes out the articles that were categorised and coded as relevant $(n=141)$ during the first coding cycle. Pattern codes are different summarisers like categories or themes and causes or explanations that can emerge from the data (Miles and Huberman, 1994). We used values coding and evaluation coding as coding methods as they are suited to exploring cultural values and analysis of public policy and programmes significance (Saldaña, 2013). As an outcome of the second coding cycle, we constructed three different imprints relating to when and from what perspective, Silicon Valley was originally introduced to the readership of Helsingin Sanomat in Finland and made available as an imprint or resource injection in the EE context. We finally analysed the identified imprints against the chronological case story to triangulate the findings and depict them against the contextual conditions of the Finnish EE in time.

In addition, to improve our analysis regarding Silicon Valley, we also used a 25-pagelong historical development analysis of Silicon Valley, which enabled us to define its imprint characteristics of the perspective of venture capital-financed entrepreneurship in time and contextualise the newspaper data in light of its history (see below). Overall, the documentation of the early development of Silicon Valley indicates that by the beginning of our observation period (1980) it was evident that the particular region was well-known inside and outside the US and attracted significant attention from policymakers and practitioners (Leslie and Kargon, 1996, p. 436). Therefore, we see that it is reasonable to assume that imprint characteristics specific to Silicon Valley were potentially available or 
achievable during our observation period to relevant stakeholders in Finland, in particular towards the end of the observation period in 1997, making our research design valid on this part. In addition, the Silicon Valley imprint characteristics open up the American mode of start-up growth that was referred to above relating to start-up and venture capital coevolution of Israel.

\section{Venture capital-financed entrepreneurship of Silicon Valley}

Silicon Valley in California is known as the birthplace of successful high-tech firms and a substantial venture capital market as a funding model to support their establishment, growth and successful exit. The beginning and development of Silicon Valley, its key industries (e.g. semiconductors) and individuals, are well-documented and debated (Saxenian, 1994; Leslie and Kargon, 1996; Kenney, 2000; Shurkin, 2006; Lécuyer, 2006; Adams et al., 2018). For this study, the most salient characteristics reside in the development of venture capital-financed entrepreneurship.

The co-evolution of venture capital is an inseparable part of Silicon Valley's development. The venture capital industry emerged after the Second World War in the US (Hambrecht, 1984, pp. 74-75) and the first modern venture capital firm, American Research and Development Corporation (ARDC), which began to invest in new high-technology firms, was established in Boston in 1946 (Gompers, 1994). A similar development took place in Silicon Valley from the early 1950s onwards when a circle of friends called "The Group" began to make investments in high-technology firms (Gupta, 2000). Local venture capital partnerships developed from the 1960s onwards when, for instance, Arthur Rock, who had organised finance for Fairchild Semiconductor in 1957, created a venture capital fund in partnership with Thomas Davis (Davis and Rock) in 1961. Sutter Hill (established in 1964), Mayfield Fund (1969), Kleiner Perkins (1972) and Sequoia Capital (1972) are amongst the well-known venture capital partnerships established afterwards. The Silicon Valley-based venture capital-financed success stories include firms such as Apple (IPO 1980), Atari (IPO 1981), Genentech (IPO 1980) and Intel (IPO 1971) that were instrumental in creating new industries for Silicon Valley-based firms to operate in beside the historically important semiconductor field (Ante, 2008).

The regular emergence of successful firms generated enormous capital gains that led to further investments in new ventures and venture capital funds - a self-reinforcing process was set in motion and established during the 1970s (Kenney and von Burg, 1999). The number of high-growth-oriented firms and venture capital investment began to grow rapidly and reached the billion-dollar annual investment level for the first time in 1986 when 340 high-technology firms in Silicon Valley raised USD 1,016m of venture capital in total (NVCA, 2013). The venture capital-financed entrepreneurship activity continued to grow substantially and in 1997, at the end of the observation period of this study, 867 Silicon Valley-based high-technology firms raised over USD 4.6bn of venture capital finance in total (NVCA, 2013).

Hambrecht (1984) observes that it was the willingness to finance risk, the increase in venture capital and the availability of local role model entrepreneurs for future entrepreneurs that set Silicon Valley apart from other regions with similar potential in the US. At the EE level, the region's historically situated events function as a pool of collective memories that affect the thinking of EE members (Lippmann and Aldrich, 2016). Business opportunities of nascent high-technology firms are approached from a high-risk and potentially high-reward perspective and resources are allocated to start-ups with the assumed potential to become the next "home run"- a firm that develops from an idea to reach an IPO. Such home run-thinking institutionalised to the sediment of the venture- 
JEEE
14,3

482

capital financed entrepreneurship culture in the 1970s (Gompers, 1994) and came to define the collective opportunity beliefs and rules of the game from this informal institution perspective (cf. Mainela et al., 2018).

In summary, it can be concluded that the EE of Silicon Valley had evolved from birth in the 1950s and 1960s to the phase of becoming established and well-functioning by the 1980s. The distinctive capability of Silicon Valley to generate successful firms and regional economic growth had triggered a significant amount of research and a constant flow, as Miller and Cote (1985) note, of planning bodies and government agencies from all over the world who visit search for ways to replicate this success in their own regions. The attempts to replicate indicate that during this period, Silicon Valley was established as an imprint, carrying the notions of venture capital-financed entrepreneurship and related risk-taking and home-run exits as culturally defining ecosystem-level institutions.

\section{Findings}

We were able to specify three key Silicon Valley imprints in Finland at the birth and early growth phases of the Finnish EE. Out of the three, we saw two as being more dominant and partly overlapping: Silicon Valley as a technology park and Silicon Valley as a taken-forgranted. A third, weaker imprint, was Silicon Valley entrepreneurship and venture capital. In the following, we first discuss the imprints and then interpret them against the contextual conditions of the Finnish EE in time.

\section{Silicon Valley as a technology park}

A central finding emerging from the data is the imprint of Silicon Valley as a technology park. A significant share of the analysed news $(n=61)$ addressed high-technology firms as a key structural component of its EE. At the beginning of the observation period, the related reporting concerned the original Silicon Valley. News reports between 1980 and $1982(n=4)$ opened up the origins of Silicon Valley through the activities of Frederick Terman at Stanford University and technology firms at Stanford Industrial Park. This was coupled with reporting underlining the importance of university-industry collaboration and support for industry research and development (R\&D) in Finland, with mentions of Silicon Valley as a successful example to justify the claims. This news represents the majority of analysed articles at the beginning of the 1980s (Figure 1).

From 1983 onwards we observe a change in the data. Instead of reporting about Silicon Valley, a process of setting up "silicon valleys" in Finland takes the main role. This development means the establishment of many technology parks in Finland, which are referred to as local silicon valleys. The reporting defines them mainly as real estate firms that pool both incumbent and nascent high-technology firms in office buildings to pay rent and access service providers. A news report from 1983 covering the establishment of the first technology park in the city of Oulu mentions that the idea is similar to Stanford University, where high-technology firms reside close to the university. This development was put in motion in 1984 by the Minister of Trade and Industry of Finland, who was reported to have visited the city of Oulu [4], referred then in the article as the Silicon Valley of Finland. The minister's central message was that the regional development policy focus will change from traditional industry park development towards the establishment of Oululike silicon valleys. A key observation here is the inherent assumption that Silicon Valley can be created or duplicated primarily by building the required real estate close to a university to form a technology park and by renting the office space to both nascent and established high-technology firms and related service providers. According to the data, there was a total of 10 of these technology park-silicon valleys in Finland by 1996. 
After the mid-1980s criticism and controversy towards the establishment of technology parks, praise began to emerge. Data shows that in 1987 Finland was seen to be behind Europe in this trend and, at the same time, the ability of the Finnish silicon valleys to survive was challenged. In 1991 it is reported that a study wrecked the myth of the Espoo region being the Finnish Silicon Valley. With respect to the US, it was reported that the technology park boom had started in the US in the 1960s and cooled down in the 1970s, with the recognition that a fancy name was not ultimately a guarantee of the quality of the activity. However, in 1996 it was reported that successful technology parks were growing and needed more space in Finland. Furthermore, the data indicates that the "technology park equals Silicon Valley" trend was taking place not only in many regions inside Finland but in other countries as well. Regions in Australia, Bulgaria, France, Japan, the Soviet Union, Sweden, Vietnam and West Germany were covered in the data as executing policies for high-technology development and entrepreneurship with reference to Silicon Valley.

News reports further illustrate how the increased national investments in technology in Finland benefited the R\&D of Finnish corporations such as Nokia and Vaisala; they were both reported to have opened their first offices in Silicon Valley in 1984 to better access technology locally. Moreover, Valmet, a government-controlled industrial corporation, was mentioned to have an affiliated firm in Silicon Valley by 1981. The role of large firms and "flagship" corporations was crucial (Rothwell, 1989) for the economy and job creation in Finland.

\section{Silicon Valley as taken-for-granted}

The assumption that the various characteristics of Silicon Valley are generally known arises of the newspaper data as a second central imprint. We categorised 75 news articles in total that used the term Silicon Valley or silicon valley as a taken-for-granted-concept, metaphor or marketing buzzword that is assumed to be generally known. The peak year for this was 1985 when 20 news articles in the data were categorised under this imprint. In comparison to Silicon Valley as a technology park-imprint of above, the main difference in these stories is that the known elements of the actual Silicon Valley are not written about but assumed to be mainstream and known by the readership and often the term or name at issue is the only indication used.

The topics of the news reports categorised under this imprint vary significantly. Some of the articles relate to regional and political developments and related public discussion in different parts of Finland. A common thread found in these stories was that either the locally developing high-technology entrepreneurship activity was given a stamp of quality or justification by calling it the local silicon valley or related development was criticised. Examples of this are reports of a city with a population of 10,000 stating the ambition to become one of the silicon valleys of Finland and a municipality of 2,000 inhabitants struggling with unemployment in 1987 that was "not dreaming of becoming a Silicon Valley".

On the other hand, many of these articles also covered some aspects of high-technology entrepreneurship and related development internationally. For instance, in 1985 the then Prime Minister of Finland was reported to have visited the Cambridge region in the UK, which is often referred to as the British Silicon Valley, without further discussion of the actual Silicon Valley. There were multiple news reports mentioning how silicon valleys are being built both in different areas inside Finland and internationally, in regions like the French Riviera, without any discussion of the original Silicon Valley. This overlaps with the view of approaching Silicon Valley as a technology park. Together with the Silicon Valley as 


\section{JEEE 14,3}

technology-park imprints, these represent the majority of news articles in the analysed data (Figure 1).

The above indicates the view of optionality; one can claim to be or not to be a silicon valley upfront by setting up structure or facilities for entrepreneurs instead of being merited with the silicon valley association after the regional emergence of internationally successful high-technology firms-the outcome of the activity of the EE itself. The regional development, industrialisation and urbanisation of Finland were topics in many news reports that used silicon valley in a positive or negative light, depending on the viewpoint and the type of news (editorial, opinion piece, news report).

\section{Silicon Valley entrepreneurship and venture capital}

Our analysis shows that news focussing on entrepreneurs of Silicon Valley high-technology firms, venture capital and related culture were not strongly present as an imprint in the data. A news report in 1980 titled "One computer firm established weekly in Silicon Valley" covers the development of Hewlett-Packard out of a garage into a then 1.7bn-dollar revenue success story, a home run with 50,000 employees of which 500 were mentioned to be millionaires. The report further mentions that its founders were amongst the richest people in the US and were at the time of founding supported by Frederick Terman of Stanford University and its entrepreneurship-friendly culture. The report also remarks on the Apple founders (Steve Jobs and Steve Wozniak) as a new generation of electronics wizards. Steve Jobs was later reported to have left Apple in 1985.

A second news report in 1980 focusses on university-industry relationships and mentions how Stanford University has spawned hundreds of firms in which university personnel are founders or act as consultants [5]. In 1985 it was reported that in Silicon Valley a person with a technological idea can get funding from willing investors and become a millionaire in true American-dream fashion. Another opinion piece in 1985 states that Silicon Valley is a mirage and the best version of it for Finland would be firms that aim to market leadership in their own specific markets. Similarly, in 1987 it is reported that the management of Finnish technology parks and resident firms like to tell stories of Silicon Valley in general and Apple in particular. In this respect, in 1997 Mike Markkula, a central figure of the early days of Apple who had family ties to Finland, is featured in relation to the success of Apple. A 1988 interview with Judith Larsen, the co-author of a Silicon Valley-related book, brings forth a view of Silicon Valley as a mindset and a culture associated with risk-taking and rapid success but also personal pressures, relationship problems and divorce as the other side of the coin. In addition, an opinion piece from 1991 mentions the attractiveness of entrepreneurship, as top university graduates in Silicon Valley choose to start their own firms instead of joining the workforce of corporations. However, outside the above eight instances, detailed news reports covering more entrepreneurial success stories and culture as imprints were not found in the newspaper data.

Venture capital was mentioned in connection to Silicon Valley for the first time in 1988 in a news report on venture capital in Europe. The report discussed how venture capital does not yet have an established definition in Finland and laymen associate it with Silicon Valley. Finnish firms are documented as not understanding venture capital activity well and not fully trusting venture capitalists and that the development of the Finnish venture capital market was lagging in comparison to other Western European countries. The second news article relating to venture capital in 1988 concerned the establishment of a new funding institution in the then Soviet Union, including references to the importance of venture capital behind the information technology firms of Silicon Valley. News about venture capital activity in Silicon Valley was not found in the data, although based on the archival data we calculate that the annual venture capital investment at its EE exceeded the billion-dollar level in 1986 already. 
The archival data enables to position and interpret the identified Silicon Valley imprints to the contextual conditions of the Finnish EE in time. Firstly, we find the weak imprint of Silicon Valley entrepreneurship and particularly venture capital supported by the analysed documents concerning the early development of venture capital-financed entrepreneurship in Finland. From the structural evolution and resource endowment perspective of the EE, the start-up and venture capital co-evolution begun in Finland already in 1967 with the establishment of the first venture capital firm (Sponsor) by the Bank of Finland. By 1983 there were nine public and only one private venture capital firm in Finland. In addition, eight more regional venture capital funds were created between 1991 and 1995 in major university cities [6]. The funds were small in size (a few million euros) and venture capitalfinanced entrepreneurship remained rather small-scale as illustrated by the annual investment volume and average investment size (Table 1).

The Finnish Industry Investment (FII), a government-owned investment firm was established in 1995 with the mandate to develop the domestic venture capital industry and help potential Finnish start-ups to grow internationally. After this, the investment activity began to grow driven by the emerging start-up boom towards the internet-the bubble burst in 2000 and the establishment of new FII-financed funds with $171 \mathrm{~m}$ euros annual investment as the peak amount in 2001. However, we found that a limited number of success stories and positive exits of venture capital-financed firms as an outcome of the EE activity remained a challenge because the annual investment level decreased to between 69 and $129 \mathrm{~m}$ euros of 2003 and 2013, respectively, with public finance having still a central role (Saarikoski et al., 2014). The policy-triggered start-up and venture capital co-evolution did not lead to the emergence of the private and growing domestic venture capital market.

The role of entrepreneurship culture and informal institutions rises as an important contextual imprint in explaining the above resource endowment development of the Finnish EE. The establishment of the new venture capital funds represents the sensitive period and moment when imprinting of contextual factors took place. The modus operandi for the majority of the new public funds, particularly until the formation of FII, was based on imprinted characteristics coming from the political resources and goals of regional, technology and employment policy rather than characteristics relating to building firms that aim to grow towards an exit. The culture and rules of the game regarding the approach to venture capital-financed entrepreneurship of this perspective have roots in the formation of Sponsor in 1967.

Sponsor was initially organised not as a for-profit nor exit-aiming venture capital firm but as a governmental development company whose functioning was affected by regional and employment policy goals (Luukkonen, 2006). This meant that it began to finance many types of firms at different development phases and business situations (for example, to save firms from bankruptcy) instead of focussing on growth- and exit-orientated start-ups. More importantly, the additional new funds established by the early 1990s were mostly public funds and subjects of imprinting by similar characteristics as they were managed by

\begin{tabular}{lcccccccc}
\hline Year & 1990 & 1991 & 1992 & 1993 & 1994 & 1995 & 1996 & 1997 \\
\hline Venture capital investment $(\mathrm{M} €)$ & 10 & 14 & 9 & 16 & 14 & 15 & 27 & 57 \\
Number of deals & 55 & 77 & 54 & 67 & 77 & 80 & 88 & 108 \\
Average investment $(\mathrm{M} €)$ & 0.18 & 0.18 & 0.17 & 0.24 & 0.18 & 0.19 & 0.31 & 0.53
\end{tabular}

Table 1. Annual venture capital investment in Finland 1990-1997 (calculated from FVCA yearbooks) 
existing regional development companies and their functioning was, hence, stamped by then central regional, technology and employment (job creation) policy goals. As the venture capital fund life cycle is long and the number of private venture capital funds remained small, these imprinted characteristics were persistent over time in the activity of the funds, and hence acted as culturally defining and resisting to change during the early evolution of the Finnish EE.

Indeed, the aspiring entrepreneurs and start-ups in dialogue and financed by the venture capital firms during the almost three decades between 1967 and mid-1990s were, at large, exposed and imprinted by venture capital finance characteristics and entrepreneurship culture of the above perspective. This resulted in start-up and venture capital co-evolution with a cultural modus operandi that stemmed not from the American or Silicon Valley-type of start-up growth but consisted of a more diverse and unclear view of what venture capital is and for what types of firms and purposes. The findings of archival data analysis covering venture capital market developments in the 1980s and 1990s support this view. Many reports found that in the 1980s and 1990s entrepreneurs were not fully aware of the possibilities of venture capital as some examples of poorly managed investments, the lack of success stories and the activity of development company venture capitalists caused mixed feelings of venture capital amongst entrepreneurs. For example, it was common that exit strategies had not been discussed or agreed upon in the 1980s, as development companies were not targeting solely them with their investments due to other goals set in policies. The venture capitalist as for were noted to be lacking in experience and connections to international and more experienced venture capitalists and partly restricted by investment bookkeeping requirements of Finnish law (formal institution). The American model of venture capital was found difficult to work in Finland because of these reasons.

Moreover, some Finnish venture capital investors expressed a struggle with the growth motivation of the financed entrepreneurs: after a promising start and growth of the firm the entrepreneurs stated the lack of willingness to grow the business further but were instead satisfied with the current firm state. This illustrates how the venture capital model with an inherent need for an exit had not been imprinted in the entrepreneurship culture domain as a rule of the game. The analysed reports suggest that although the number of established new firms was amongst the highest in proportion to population and entrepreneurship was appreciated in Finland (Auer, 1990) and some imprints of Silicon Valley success stories were found above, a renewal of entrepreneurship culture was needed. At the same time, reports document that the Finnish venture capitalists should be connected to more experienced foreign venture capitalists to learn from them. However, when we analysed this development, a booklet covering the Finnish venture capital investors in 1995 reveals that there are no foreign partners as members of the fund management teams. It is possible that the political resource imprints of the noted policy areas have been preferred instead of moving clearly to the exit-orientated venture capital of which inclusion of foreign venture capitalists would have signalled.

In sum, the formulation and imprinting of venture capital-financed entrepreneurship culture in parallel with start-up and venture capital co-evolution can be seen to have roots in the objectives and views set in policies relating to venture capital market development. In Finland, these policies build upon layers of imprints that originate from regional and technology development and employment growth aspirations which were established before venture capital activity entered the political agenda. When venture capital market development became relevant these prior policy goals persisted as imprints coming from the local context and became to define the informal institutions and entrepreneurship culture concerning venture capital-financed entrepreneurship. Neither the newspaper nor archival 
data contained the Silicon Valley nor American mode of start-up growth as the informal institution-level modus operandi that would become to define and direct start-up and venture capital co-evolution in Finland.

Finally, relating to contextualising of the imprints of Silicon Valley as a technology park and taken-for-granted, the archival data analysis shows that these imprints are supported by a major transition in technology policy in Finland. In the early 1980s, Finland was considered to be lacking in industrial renewal capability and the ability to create technologically sophisticated industries and to be behind OECD countries in terms of national R\&D investment. This technological catch-up position was addressed by new policies and institutions to finance technological development and increase cooperation between universities, research institutes and firms in general and under national technology programmes in particular. The policies resulted in the establishment of a large number of organisations and infrastructure such as the network of technology parks, technology transfer companies and business incubators and an increase of R\&D funding and venture capital finance (Lemola, 2002). This development was strongly coupled with the gradually increasing Nokia-driven significant employment growth and success in the technology sector and the establishment of many high-technology firms to support the needs of Nokia (Ali-Yrkkö and Hermans, 2002). Combined, this meant that Nokia and the high-technology firms needed new office space in many technology parks across Finland.

We see that a higher amount of Silicon Valley as a technology park and taken-forgranted imprints in the results contextualise against this nation-wide development that was in a central role in raising the Nokia-driven Finland amongst the most innovative and competitive countries by the late-1990s. For the early evolution of the Finnish EE, this meant that conditions for entrepreneurship improved on the level of many EE components such as physical and financial resources, human capital and knowledge. However, this was not (yet) driven by successful start-up and venture capital co-evolution and generation of venturecapital financed success stories as the agency for the structure coming of the entrepreneurship culture level emphasised the wide-ranging policy goals.

\section{Discussion}

EE has recently emerged as a promising research topic of systemic entrepreneurship and a policy tool for entrepreneurship-led economic development. In this paper, we focussed on a subset of EE structure (Cavallo et al., 2019) by analysing how entrepreneurship culture affects the start-up and venture capital co-evolution during the early evolution of EE. This study contributes to the EE literature in several ways.

Firstly, we find that while prior research documents entrepreneurship culture as an important element within the institutional arrangement of an EE, the majority of studies capture it on a national or societal level. Our results indicate that venture capital-financed entrepreneurship and the emergence of success stories as outcomes of start-up and venture capital co-evolution within EE are connected to a specific type of entrepreneurship culture. This culture of venture capital-financed entrepreneurship can vary across territories and its alignment with the principles of venture capital finance cannot be taken as a given. Our findings illustrate how during the early evolution of the Finnish EE, the local venture capital-financed entrepreneurship culture was mainly built and mediated by targets set in many policy fields which resulted in an embedded cultural modus operandi that was not aligned with the principle of private venture capital-financed firms needing to achieve an exit. We referred to the latter principle as the American and Silicon Valley start-up mode and found that-unlike in the start-up and venture capital co-evolution of Israel-it was not strongly present as an imprint at the entrepreneurship culture level in Finland when start-up 
JEEE 14,3

488

and venture capital co-evolution began within the Finnish EE. Although venture capital policies improved access to venture capital finance and increased resource allocation to firms within the Finnish EE (Acs et al., 2017), the specific modus operandi at the cultural level allocated resources for long to firms that did not aim to grow towards an exit. The findings help to explain the identified long-standing performance challenges of the Finnish EE until the recent decade. Our results illustrate venture capital-financed entrepreneurship culture as an example of entrepreneurship culture beneath the national level (Credit et al., 2018), an informal institution that matters and have an impact on structural evolution and performance of EEs (Alvedalen and Boschma, 2017) and to the ways how EEs deliver or fail to deliver benefits to entrepreneurs (Spigel and Harrison, 2018).

As a second and related contribution, we connect the fundamentals of organisational imprinting to EE research. Our results of start-up and venture capital co-evolution in Finland show how the notion of a sensitive period, imprinting of environmental factors and particularly the persistence of imprints over time are useful concepts in EE research. We found that the initial imprints, which during the early evolution of the Finnish EE became to define the culture of venture capital-financed entrepreneurship, institutionalised and were long-lasting rules of the game. The initial venture capital funds as new institutions were first imprinted by contextual conditions of policymakers and the funds then exposed entrepreneurs and start-ups to the same imprint characteristics when they sought to finance and partner with the venture capitalists within the EE. We see organisational imprinting to have potential especially for studies that address the connections between institutional arrangement and resource endowment elements of EEs and their co-evolution over time (Alvedalen and Boschma, 2017; Stam and van de Ven, 2019).

Thirdly, the globalisation of venture capital (Florida and Hathaway, 2018) and the emergence of unicorns underline the importance of start-up and venture capital co-evolution in EE development. For policymakers involved in venture capital market initiatives, our results show that the informal institution element-venture capital-financed entrepreneurship culture- is an integral part of the start-up and venture capital co-evolution and a key modus operandi in defining the development of venture capital-financed entrepreneurship, and therefore outcomes of EE activity. The findings concerning the Finnish EE indicate that although policymakers have also other policy areas addressable at the same time with venture capital policy and political pressure to show parliamentary term results in areas such as regional job creation and employment policy, the goals of these policies should not be brought to mediate and imprint venture capital policy and the investment activity of the established funds. This can result in an unclear understanding of venture capital as a new institution and rules of the game that do not relate to the principles of venture capital and hamper the goal of developing a domestic venture capital industry and the emergence of success stories. Secondly, our results support the view that policymakers should pay attention to the initial management teams of venture capital funds and make sure that experienced investors with the right informal institution understanding of venture capital are found to support the development of the domestic venture capital investor field (Avnimelech and Teubal, 2006). This can ensure that the culture of venture capital-financed entrepreneurship is aligned with the principles of venture capital and imprinted to the co-evolution with the funded start-ups which is relevant especially in the context of emerging economies that can lack such capability domestically at the early evolution phase.

Our research comes with the following limitations and suggestions for future research. Although the use of one national newspaper, like Helsingin Sanomat, is considered to be a valid source of data (Barranco and Wisler, 1999) and we use extensive archival data for 
capturing the contextual conditions and development of the entrepreneurial context of Finland, further studies could analyse Silicon Valley and the American start-up mode -related reporting in other newspapers and periodicals. It is possible that discourse relating to them in the media under other related topics such as well-known individual entrepreneurs, managers or successful firms, are not covered, thus limiting the generalisation and validity of the results. This aspect of the related imprints is an area to be covered in future studies of the topic and could be improved by interviews of contemporary key stakeholders.

Finally, regarding future research of on-going start-up and venture capital co-evolution (Karsai, 2018) and its implication on performance of EEs, our findings suggest that the inclusion of venture capital-financed entrepreneurship culture as its own observable element could increase the impact of these studies, particularly during the early evolution of EEs when initial institutions are created.

\section{Notes}

1. http://europa.eu/rapid/press-release_IP-16-3882_en.htm (accessed 10.12.2020).

2. www.cbinsights.com/research-unicorn-companies (accessed 10.12.2020).

3. We did not use coding and analysis software such as NVivo because significant share of the newspaper articles was saved in the database of Helsingin Sanoma using image format that was not machine readable or editable. The images were printed in paper and coded manually and categorised using spreadsheet software.

4. The ICT industry and Nokia became the key drivers of regional growth-the Oulu Phenomenonof the city of Oulu from the 1980s onwards until the collapse of Nokia's mobile phone business in the early 2010s.

5. The role of Stanford University is over-stated in this connection by the reporter. The research of Lécuyer (2006), for instance, has later shows that by 1980 none of the then central semiconductor firms were Stanford spin-offs or located to the Stanford Industrial Park.

6. This development took place in parallel with the severe economic recession of Finland in the early 1990s (Kiander and Vartia, 1996) which resulted in the reorganization of the whole banking sector and caused Finnish industrial policy to focus on small and medium-sized enterprises (SMEs) and their finance (Hyytinen and Väänänen, 2002).

\section{References}

Acs, Z.J., Autio, E. and Szerb, L. (2014), "National systems of entrepreneurship: measurement issues and policy implications”, Research Policy, Vol. 43 No. 3, pp. 476-494, doi: 10.1016/j.respol.2013.08.016.

Acs, Z.J., Stam, E., Audretsch, D.B. and O'Connor, A. (2017), "The lineages of the entrepreneurial ecosystem approach", Small Business Economics, Vol. 49 No. 1, pp. 1-10.

Adams, S.B., Chambers, D. and Schultz, M. (2018), "A moving target: the geographic evolution of Silicon Valley, 1953-1990”, Business History, Vol. 60 No. 6, pp. 859-883.

Adner, R. and Kapoor, R. (2010), "Value creation in innovation ecosystems: how the structure of technological interdependence affects firm performance in new technology generations", Strategic Management Journal, Vol. 31 No. 3, pp. 306-333.

Ali-Yrkkö, J. and Hermans, R. (2002), "Nokia in the Finnish innovation system”, Discussion paper No. 881, The Research Institute of the Finnish Economy (ETLA), Helsinki.

Alvedalen, J. and Boschma, R. (2017), "A critical review of entrepreneurial ecosystems research: towards a future research agenda”, European Planning Studies, Vol. 25 No. 6, pp. 887-903. 
Andersson, M. and Henrekson, M. (2015), "Local competitiveness fostered through local institutions for entrepreneurship", in Audretsch, D.B., Link, A.N. and Walshok, M.L. (Eds), The Oxford Handbook of Local Competitiveness, Oxford University Press, Oxford, pp. 145-190.

Ante, S.E. (2008), Creative Capital: Georges Doriot and the Birth of Venture Capital, Harvard Business Press, Cambridge MA.

Auer, J. (1990), The Venture Capital Industry in the USA, Europe and Finland: Development, Environment and Incentives, Finnish National Fund for Research and Development, Helsinki.

Auerswald, P.E. (2015), "Enabling entrepreneurial ecosystems: insights from ecology to inform effective entrepreneurship policy”, Kauffman Foundation Research Series on City, Metro, and Regional Entrepreneurship.

Autio, E. (2009), "The Finnish paradox: the curious absence of high-growth entrepreneurship in Finland", Discussion paper No. 1197, ETLA, Helsinki.

Autio, E., Kenney, M., Mustar, P., Siegel, D. and Wright, M. (2014), "Entrepreneurial innovation: the importance of context”, Research Policy, Vol. 43 No. 7, pp. 1097-1108.

Avnimelech, G. and Teubal, M. (2006), "Creating venture capital industries that co-evolve with high tech: insights from an extended industry life cycle perspective of the Israeli experience", Research Policy, Vol. 35 No. 10, pp. 1477-1498.

Bahrami, H. and Evans, S. (1995), "Flexible re-cycling and high-technology entrepreneurship", California Management Review, Vol. 37 No. 3, pp. 62-89.

Barley, S.R. and Tolbert, P.S. (1997), "Institutionalization and structuration: studying the links between action and institution", Organization Studies, Vol. 18 No. 1, pp. 93-117.

Barranco, J. and Wisler, D. (1999), "Validity and systematicity of newspaper data in event analysis", European Sociological Review, Vol. 15 No. 3, pp. 301-322.

Blakely, E.J. and Leigh, N.G. (2010), Planning Local Economic Development: Theory and Practice, SAGE Publications, Thousand Oaks, CA.

Breznitz, D. (2006), "Innovation-based industrial policy in emerging economies? The case of Israel's IT industry", Business and Politics, Vol. 8 No. 3, pp. 1-38.

Breznitz, D. (2007), "Industrial R\&D as a national policy: horizontal technology policies and industrystate co-evolution in the growth of the Israeli software industry", Research Policy, Vol. 36 No. 9 , pp. 1465-1482.

Carrol, G.R. and Hannan, M.T. (2004), The Demography of Corporations and Industries, Princeton University Press, Princeton, NJ.

Cavallo, A., Ghezzi, A. and Balocco, R. (2019), "Entrepreneurial ecosystem research: present debates and future directions", International Entrepreneurship and Management Journal, Vol. 15 No. 4, pp. 1291-1321.

Crawford, G.C., Aguinis, H., Lichtenstein, B., Davidsson, P. and McKelvey, B. (2015), "Power law distributions in entrepreneurship: implications for theory and research", Journal of Business Venturing, Vol. 30 No. 5, pp. 696-713.

Credit, K., Mack, E.A. and Mayer, H. (2018), "State of the field: data and metrics for geographic analyses of entrepreneurial ecosystems", Geography Compass, Vol. 12 No. 9, p. e12380.

Cuervo-Cazurra, A., Andersson, U., Brannen, M.Y., Nielsen, B.B. and Reuber, A.R. (2016), "From the editors: can I trust your findings? Ruling out alternative explanations in international business research", Journal of International Business Studies, Vol. 47 No. 8, pp. 881-897.

Deschryvere, M. (2008), "High growth firms and job creation in Finland", Discussion paper No. 1144, ETLA, Helsinki.

Dutta, S., Lanvin, B. and Wunsch-Vincent, S. (2017), "The global innovation index 2014: the human factor in innovation", available at: www.globalinnovationindex.org/gii-2017-report 
Feld, B. (2012), Startup Communities: Building an Entrepreneurial Ecosystem in Your City, Wiley, Hoboken NJ.

Florida, R. and Hathaway, I. (2018), "Rise of the global startup city - the new map of entrepreneurship and venture capital”, Center for American Entrepreneurship, available at: http://startupsusa.org/ global-startup-cities/\#appendix

Fritsch, M. and Wyrwich, M. (2014), "The long persistence of regional levels of entrepreneurship: Germany, 1925-2005”, Regional Studies, Vol. 48 No. 6, pp. 955-973.

Gephart, R.P. (2004), "Qualitative research and the academy of management", Academy of Management Journal, Vol. 47 No. 4, pp. 454-462.

Gertler, M.S. (2004), Manufacturing Culture: The Institutional Geography of Industrial Practice, Oxford University Press, Oxford.

Gertler, M.S. (2010), "Rules of the game: the place of institutions in regional economic change", Regional Studies, Vol. 44 No. 1, pp. 1-15.

Ghauri, P. (2004), "Designing and conducting case studies in international business research", in Marschan-Piekkari, R. and Welch, C. (Eds), Handbook of Qualitative Research Methods for International Business, Edward Elgar Publishing, Cheltenham, pp. 109-124.

Gomes, L.A.V., Facin, A.L.F., Salerno, M.S. and Ikenami, R.K. (2016), "Unpacking the innovation ecosystem construct: evolution, gaps and trends", Technological Forecasting and Social Change, Vol. 136, pp. 30-48, doi: 10.1016/j.techfore.2016.11.009.

Gompers, P. (1994), “The rise and fall of venture capital”, Business and Economic History, Vol. 23 No. 2, pp. 1-26.

Gompers, P. and Lerner, J. (2004), The Venture Capital Cycle, MIT Press, Boston, MA.

Gupta, U. (2000), "Done Deals: Venture Capitalists Tell Their Stories, Harvard Business Press, Boston, MA.

Hambrecht, W. (1984), "Venture capital and the growth of Silicon Valley", California Management Review, Vol. 26 No. 2, pp. 74-82.

Hannan, M.T., Burton, M.D. and Baron, J.N. (1996), "Inertia and change in the early years: employment relations in young, high technology firms", Industrial and Corporate Change, Vol. 5 No. 2, pp. 503-536.

Harima, A., Harima, J. and Freiling, J. (2020), "The injection of resources by transnational entrepreneurs: towards a model of the early evolution of an entrepreneurial ecosystem", Entrepreneurship and Regional Development, pp. 1-28.

Hayton, J.C. and Cacciotti, G. (2013), "Is there an entrepreneurial culture? A review of empirical research", Entrepreneurship and Regional Development, Vol. 25 Nos 9/10, pp. 708-731, doi: 10.1080/08985626.2013.862962.

Hyytinen, A. and Väänänen, L. (2002), "Government funding of small and medium-sized enterprises in Finland”, ETLA Discussion Papers 832, ETLA, Helsinki.

Immelmann, K. (1975), "Ecological significance of imprinting and early learning", Annual Review of Ecology and Systematics, Vol. 6 No. 1, pp. 15-37.

Isenberg, D.J. (2010), “The big idea: how to start an entrepreneurial revolution”, Harvard Business Review, Vol. 88, pp. 40-50.

Jacobides, M.G., Cennamo, C. and Gawer, A. (2018), "Towards a theory of ecosystems", Strategic Management Journal, Vol. 39 No. 8, pp. 2255-2276.

Johnson, V. (2007), "What is organisational imprinting? Cultural entrepreneurship in the founding of the Paris Opera”, American Journal of Sociology, Vol. 113 No. 1, pp. 97-127.

Kapoor, R. and Lee, J.M. (2013), "Coordinating and competing in ecosystems: how organisational forms shape new technology investments", Strategic Management Journal, Vol. 34 No. 3, pp. 274-296. 
Karsai, J. (2018), “Government venture capital in Central and Eastern Europe”, Venture Capital, Vol. 20 No. 1, pp. 73-102.

Kenney, M. (Ed.), (2000), Understanding Silicon Valley: The Anatomy of an Entrepreneurial Region, Stanford University Press, Stanford, CA.

Kenney, M. and Von Burg, U. (1999), "Technology, entrepreneurship and path dependence: industrial clustering in Silicon Valley and Route 128", Industrial and Corporate Change, Vol. 8 No. 1, pp. 67-103.

Kiander, J. and Vartia, P. (1996), “The great depression of the 1990s in Finland”, Finnish Economic Papers, Vol. 9 No. 1, pp. 72-88.

Lécuyer, C. (2006), Making Silicon Valley: Innovation and the Growth of High Tech, 1930-1970, MIT Press, Cambridge, MA.

Lemola, T. (2002), "Convergence of national science and technology policies: the case of Finland", Research Policy, Vol. 31 Nos 8/9, pp. 1481-1490.

Lerner, J. (2009), Boulevard of Broken Dreams: Why Public Efforts to Boost Entrepreneurship and Venture Capital Have Failed - And What to Do about It, Princeton University Press, Princeton.

Leslie, S.W. and Kargon, R.H. (1996), "Selling Silicon Valley: Frederick Terman's model for regional advantage", Business History Review, Vol. 70 No. 4, pp. 435-473.

Lippmann, S. and Aldrich, H.E. (2016), "A rolling stone gathers momentum: generational units, collective memory, and entrepreneurship”, Academy of Management Review, Vol. 41 No. 4, pp. 658-675.

Luukkonen, T. (2006), "Venture capital industry in Finland: country report for the venture fun project", Discussion Paper No. 1003, ETLA, Helsinki.

Mack, E. and Mayer, H. (2016), "The evolutionary dynamics of entrepreneurial ecosystems”, Urban Studies, Vol. 53 No. 10, pp. 2118-2133.

Mainela, T., Puhakka, V. and Sipola, S. (2018), "International entrepreneurship beyond individuals and firms: on the systemic nature of international opportunities", Journal of Business Venturing, Vol. 33 No. 4, pp. 534-550.

Malecki, E.J. (2018), "Entrepreneurship and entrepreneurial ecosystems”, Geography Compass, Vol. 12 No. 3, pp. 1-21, doi: 10.1111/gec3.12359.

Marquis, C. and Tilcsik, A. (2013), "Imprinting: toward a multilevel theory", Academy of Management Annals, Vol. 7 No. 1, pp. 193-243.

Mason, C. and Brown, R. (2014), "Entrepreneurial ecosystems and growth-oriented entrepreneurship", Final Report to OECD, OECD, Paris.

Mason, C.M. and Harrison, R.T. (2006), "After the exit: acquisitions, entrepreneurial recycling and regional economic development”, Regional Studies, Vol. 40 No. 1, pp. 55-73.

Miles, M.B. and Huberman, A.M. (1994), Qualitative Data Analysis: An Expanded Source Book, 2nd ed., Sage, Thousand Oaks, CA.

Miller, R. and Cote, M. (1985), "Growing the next Silicon Valley”, Harvard Business Review, Vol. 63 No. 4, pp. 114-123.

Moore, J.F. (1993), "Predators and prey: a new ecology of competition", Harvard Business Review, Vol. 71 No. 3, pp. 75-86.

Morris, M.H., Neumeyer, X. and Kuratko, D.F. (2015), “A portfolio perspective on entrepreneurship and economic development”, Small Business Economics, Vol. 45 No. 4, pp. 713-728.

Motoyama, Y. and Knowlton, K. (2017), "Examining the connections within the startup ecosystem: a case study of St. Louis", Entrepreneurship Research Journal, Vol. 7 No. 1, pp. 1-32.

North, D.C. (1990), Institutions, Institutional Change, and Economic Performance, Cambridge University Press, Cambridge. 
NVCA (2013), Yearbook 2013, National Venture Capital Association.

Pierce, L. (2009), "Big losses in ecosystem niches: how core firm decisions drive complementary product shakeouts", Strategic Management Journal, Vol. 30 No. 3, pp. 323-347.

Rothwell, R. (1989), "Small firms, innovation and industrial change", Small Business Economics, Vol. 1 No. 1, pp. 51-64.

Roundy, P.T. (2017a), "Hybrid organizations and the logics of entrepreneurial ecosystems", International Entrepreneurship and Management Journal, Vol. 13 No. 4, pp. 1221-1237.

Roundy, P.T. (2017b), “'Small town' entrepreneurial ecosystems: implications for developed and emerging economies", Journal of Entrepreneurship in Emerging Economies, Vol. 9 No. 3, pp. 238-262.

Roundy, P.T. and Bayer, M.A. (2019), "Entrepreneurial ecosystem narratives and the micro-foundations of regional entrepreneurship", The International Journal of Entrepreneurship and Innovation, Vol. 20 No. 3, pp. 194-208.

Roundy, P.T., Bradshaw, M. and Brockman, B.K. (2018), "The emergence of entrepreneurial ecosystems: a complex adaptive system approach", Journal of Business Research, Vol. 86 No. 1, pp. 1-10, doi: 10.1016/j.jbusres.2018.01.032.

Saarikoski, M., Roine, P., Ruohonen, J., Halonen, A., Sulin, J. and Lebret, H. (2014), "Evaluation of finnish industry investment ltd", Innovation 1/2014, Ministry of Employment and the Economy, Helsinki.

Saldaña, J. (2013), The Coding Manual for Qualitative Researchers, Sage, Thousand Oaks, CA.

Saxenian, A. (1994), Regional Advantage: Culture and Competition in Silicon Valley and Route 128, Harvard University Press, Cambridge, MA.

Schwab, K. and Sala-I-Martín, X. (2016), “The Global Competitiveness Report 2016-2017”, World Economic Forum, Geneva.

Senor, D. and Singer, S. (2009), Start-up Nation: The Story of Israel's Economic Miracle, Hachette Book Group, New York, NY.

Shane, S. (2009), "Why encouraging more people to become entrepreneurs is bad public policy", Small Business Economics, Vol. 33 No. 2, pp. 141-149.

Shurkin, J.N. (2006), Broken Genius: The Rise and Fall of William Shockley, Creator of the Electronic Age, Palgrave Macmillan, New York, NY.

Simsek, Z., Fox, B.C. and Heavey, C. (2015), “What's past is prologue': a framework, review, and future directions for organizational research on imprinting", Journal of Management, Vol. 41 No. 1, pp. 288-317.

Song, A.K. (2019), "The digital entrepreneurial ecosystem - a critique and reconfiguration", Small Business Economics, Vol. 53 No. 3, pp. 569-590.

Spigel, B. (2016), "Developing and governing entrepreneurial ecosystems: the structure of entrepreneurial support programs in Edinburgh, Scotland", International Journal of Innovation and Regional Development, Vol. 7 No. 2, pp. 141-160, doi: 10.1504/IJIRD.2016.077889.

Spigel, B. (2017), "The relational organization of entrepreneurial ecosystems", Entrepreneurship Theory and Practice, Vol. 41 No. 1, pp. 49-72, doi: 10.1111/etap.12167.

Spigel, B. and Harrison, R. (2018), "Towards a process theory of entrepreneurial ecosystems”, Strategic Entrepreneurship Journal, Vol. 12 No. 1, pp. 151-168.

Stam, E. (2015), "Entrepreneurial ecosystems and regional policy: a sympathetic critique", European Planning Studies, Vol. 23 No. 9, pp. 1759-1769.

Stam, E. and Spigel, B. (2017), "Entrepreneurial ecosystems”, in Blackburn, R., De Clercq, D., Heinonen, J. and Wang, Z. (Eds), Sage Handbook for Entrepreneurship and Small Business, Sage.

Stam, E. and van de Ven, A. (2019), "Entrepreneurial ecosystem elements", Small Business Economics, Vol. 56 No. 2, doi: 10.1007/s11187-019-00270-6. 
Stinchcombe, A.L. (1965), "Social structure and organisations", in March, J.G. (Ed.), Handbook of Organization, Rand-McNally, Chicago, pp. 142-193.

Tansley, A.J. (1935), “The use and abuse of vegetational concepts and terms”, Ecology, Vol. 16 No. 3, pp. 284-307.

Tolbert, P.S. and Zucker, L.G. (1996), "Institutionalization of institutional theory", in Glegg, S., Hardy, G. and Nord, W. (Eds), The Handbook of Organization Studies, Sage, Thousand Oaks, CA, pp. 175-190.

Tsujimoto, M., Kajikawa, Y., Tomita, J. and Matsumoto, Y. (2017), “A review of the ecosystem concepttowards coherent ecosystem design", Technological Forecasting and Social Change, Vol. 136, pp. 49-58, doi: 10.1016/j.techfore.2017.06.032.

Van de Ven, A.H. (1993), “The development of an infrastructure for entrepreneurship”, Journal of Business Venturing, Vol. 8 No. 3, pp. 211-230.

Welch, C., Piekkari, R., Plakoyiannaki, E. and Paavilainen-Mäntymäki, E. (2011), “Theorising from case studies: towards a pluralist future for international business research", Journal of International Business Studies, Vol. 42 No. 5, pp. 740-762.

Williamson, O.E. (2000), "The new institutional economics: taking stock, looking ahead", Journal of Economic Literature, Vol. 38 No. 3, pp. 595-613.

Wonglimpiyarat, J. (2016), "Exploring strategic venture capital financing with silicon valley style", Technological Forecasting and Social Change, Vol. 102, pp. 80-89.

Yin, R. (1994), Case Study Research, Sage, Newbury Park, CA.

\section{Corresponding author}

Sakari Sipola can be contacted at: sakari.sipola@oulu.fi

For instructions on how to order reprints of this article, please visit our website: 